\title{
Reading Habakkuk 3 in the light of ancient unit delimiters
}

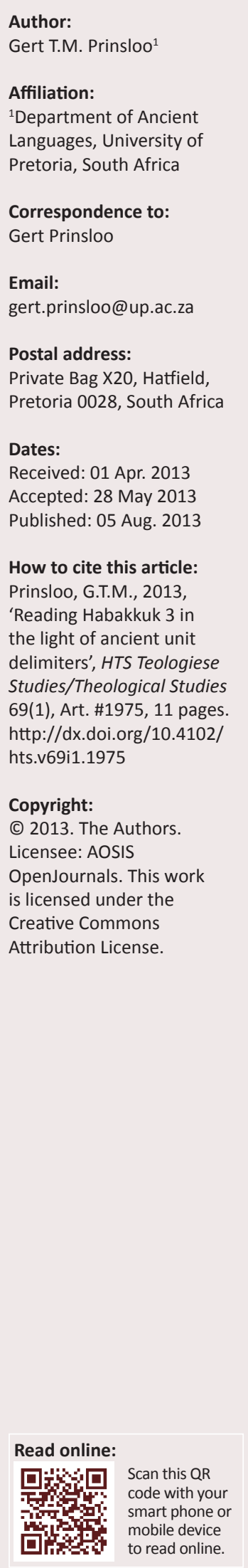

Habakkuk 3 is one of the most controversial texts in the Hebrew Bible. Diverging opinions have been expressed on literally every facet of the text. Quite surprising though, interpreters are virtually unanimous in their opinion about the structure of the pericope. Apart from a superscript (3:1) and subscript (3:19b) four units are normally demarcated: a prayer (3:2), a theophany (3:3-7), a hymn (3:8-15) and a confession of trust (3:16-19a). Unit delimiters in ancient Hebrew manuscripts demarcate two $(3: 1-13$ and $3: 14-19)$ or three $(3: 1-7 ; 3: 8-13$; 3:14-19) units. This study evaluates this evidence and reads Habakkuk 3 in the light of the units demarcated in ancient manuscripts. It raises awareness of interesting structural patterns in the poem, calls for a rethinking of traditional form critical categories, and opens avenues for an alternative understanding of the pericope.

\section{Introduction}

Habakkuk $3^{1}$ is a controversial text and presents exegetes with challenging interpretational problems covering the whole range of Hebrew Bible methodological issues. ${ }^{2}$ Apparently insurmountable text critical problems, ${ }^{3}$ as well as literary critical, redaction critical and composition critical issues cause much controversy. ${ }^{4}$ The relationship between Habakkuk 3 and other Hebrew Bible and Ancient Near Eastern texts has been debated intensely. ${ }^{5}$ Ever since the rise of modern critical scholarship these issues have been discussed in a constant stream of publications, but consensus on any one of them seems to be unattainable.

Given the wide range of opinions on all the problem areas indicated above, it is quite surprising that scholars are virtually unanimous in their opinion about the overall structure of the chapter. It is exactly on this issue that ancient Hebrew manuscripts are virtually unanimous in their disagreement with this consensus. The conspicuous disagreement between ancient unit delimiters and modern paragraph divisions in Habakkuk 3 forms the focus of this study. The research question asked in this study is: Would it influence the interpretation of Habakkuk 3 if it is read in the light of the ancient unit delimiters?

\section{The structure of Habakkuk 3: Modern critical opinions}

A mere glance at a number of influential commentaries and other studies on Habakkuk 3 makes two things clear: firstly there is a wide consensus about the structure of the pericope, secondly the consensus is largely influenced by traditional form critical classifications of the identified subunits in the pericope. Broadly speaking the chapter is approached from one of two perspectives - either a literary-critical and redaction-historical perspective or a literary perspective. ${ }^{6}$ Adherents of the

1.This study forms part of a larger research project in the field of unit delimitation in the Book of Habakkuk. Cf. Korpel (2000:1-50) for a general orientation of the method. In a previous study (Prinsloo 2009) it has been argued that unit delimiters (notably petuchot
and setumot) in ancient Hebrew manuscripts pose serious questions to modern critical scholarship's understanding of the Book of and setumot) in ancient Hebrew manuscripts pose serious questions to modern critical scholarship's understanding of the Book of
Habakkuk. The implications of unit delimiters for the interpretation of Habakkuk 1 have also been addressed in a previous publication Habakkuk. The implications of unit delimiters for the interpretation of Habakkuk 1 have also been addressed in a previous publication
(Prinsloo 2004:621-645). I dedicate this study to Prof. James Alfred Loader who had an immense influence on my formative years as an academic in the field of ancient Near Eastern languages and cultures. His professionalism made an indelible impression and his lectures on structural patterns in Hebrew Bible literature (cf. Loader 1979) forever influenced the way I read texts.

2.Cf. Dangl's (2001:131-168) overview of research on the book. He reserves a special section for Habakkuk 3 (2001:144-151) because it can be regarded as a 'distinct text within the text' (2001:144). Clark and Hatton (1989:114) regard Habakkuk 3 as 'quite different from the rest of the book in both form and content.'

3.Some regard the text as corrupt and propose numerous emendations (cf. Roberts 1991:128-144; Pfeiffer 2005:128-135); others defend the essential trustworthiness of the Masoretic text (Anderson 2001:264-268). In a previous study I defended the second position (Prinsloo 2002:83-111, esp. 88-98). I now propose alternative demarcation for a number of cola in the light of my research in the field of Unit Delimitation.

4.Dangl (2001:145-147) identifies two areas of concern: the question whether Habakkuk 3 has originally been part of the composition given its absence in 1QpHab, and the question whether Habakkuk 3 itself displays internal unity. In recent publications Albertz (2003:9given its absence in 1QpHab, and the question whether Habakkuk 3 itself displays internal unity. In recent publications Albertz (2003:910) and Pfeiffer (2005:164) answered the questions in the negative and proposed elaborate redaction-critical processes behind the book. Markl (2004:104) defends the basic unity of the book and states. "Hab 3 nimmt aufgrund der eigenen Uberschrift V. 1 und seiner besonderen Gestalt gegenüber den ersten beiden Kapiteln eine relativ eigenständige Position ein. Gleichzeitig ist der Psalm mit dem
vorangehenden Text auf vielfältige Weise verbunden und erfüllt eine komplexe funktion im Buchzusammenhang.'

5.Dangl (2001:147-149) identifies two areas of concern: on the one hand scholars wrote extensively on the relationship between Habakkuk 3 and other texts in the Hebrew Bible, on the other hand there has been intense debate on the question whether Habakkuk 3 should be read against a Babylonian, Syro-Palestinian or Egyptian mythological background (cf. Avishur 1994:124-142 for a discussion of these issues).

6.Cf. Prinsloo (2002:84-87) and Pfeiffer (2005:117-128) for overviews of the chapter's research history. 
former approach recognise various later additions to the chapter whilst adherents of the latter emphasise its literary unity. The result in terms of the description of the structure remains largely the same, summarised as follows by Pfeiffer (2005):

Läßt man zunächst die psalmenartigen Rahmenelemente V.1.19b nebst Sela-Einwürfen (V.3.9) außer acht, so gliedert sich Hab 3, 2-19a in ein durch die Thematik von Theophanie und Kampf (vgl. Jdc 5 [Judges]; Dtn 33, 2-5.26-29; Ps 68) bestimmtes Korpus (V.3-15) und einen von der Ich-Rede des Propheten dominierten Rahmen V.2.16-19. (p. 151)

A typical example of the demarcation of the structure of the text from a redaction-historical perspective is provided by Avishur (1994:111-205). ${ }^{7}$ Departing from the notation in 1b he classifies Habakkuk 3 as a national lament displaying all the characteristics of the genre, namely:

a lament about the people's present plight, accompanied by an invocation or supplication to God to deliver the people from their distress. Incorporated in such lamentations after the invocation to God is a hymn describing God's mighty deeds ... which contrasts the glorious past with the tribulations of the present. (Avishur 1994:113) ${ }^{9}$

The difference between Habakkuk 3 and comparable laments is that the quoted hymn is extraordinarily long (Avishur 1994:113-114). According to Avishur (1994:114) verses 2 and 16 form a 'framework of prayer and lamentation' bound together by the repetition of the verb שמעתי 'I have heard' (2a; 16a) and the root רגז (cf. ברגז 'in anger'10 in 2d; ארגז 'and it trembled' in 16a; 1 'I tremble' in 16c). ${ }^{11}$ The hymn consists of two units 'which differ from one another thematically and structurally, despite their common theme, God's mighty deeds' (Avishur 1994:118). The theme of the first (3:3-6) is the divine revelation at Sinai and is reminiscent of texts like Deuteronomy 33:2-3; Judges 5:4-5 and Psalm 68:8-9. It begins and ends with a reference to mountains (cf. הררי־עד 'the mountain of Paran' in 3b and 'הר־ 'the everlasting mountains' in 6c). The theme of the second (3:8-15) is YHWH's battle against the sea and rivers. It too, displays a broad chiastic pattern, beginning and ending with references to the sea and horses (cf. נהרים 'rivers' in 8ab, ים 'sea' in 8c, סוסיך 'your horses' in 8d; ים 'sea' in 15a, מים 'waters' in 15b, סוסיך 'your horses' in 15a; cf. Avishur 1994:118-119). Habakkuk 3:7 should be transposed between 3:13a and 13b (Avishur 1994:120). Habakkuk 3:17 and 3:18-19 are both secondary additions which do not fit into the original chiastic pattern of the poem (Avishur 1994:120-121). Habakkuk 3:17 is reminiscent of Joel 1:7, 10 and 18 and describes a famine, a theme foreign to the rest of the book (Avishur 1994:196-198). Habakkuk 3:18-19 is parallel to Psalm 18:33-34 and 47 (and parallel verses in $2 \mathrm{Sm} \mathrm{22}$ ) and was added to give the psalm a positive conclusion (Avishur 1994:201).

7.l use Avishur as example because he has a relatively 'mild" view on the growth of the text and focuses on its overall structure.

8.Avishur (1994:112, n. 6) associates שגינות and the related שגיון in Psalm 7:1 with the Akkadian šigû 'lament'.

9.Avishur (1994:113) classifies Psalms 74, 77 and 89 as communal laments quoting from ancient hymns and Psalms 44 and 79 as laments alluding to hymns praising God.

10.Avishur's (1994:114) translation. Hiebert (1986:4) translates 'in turmoil'.

11.Avishur (1994:115-116) perceives similarities between 3:1, 16 and communal laments (cf. Pss 44:2; 77:3-13).
From a literary perspective Habakkuk 3 is commonly regarded as a theophany (3:3-15) in two parts (3:3-7 and 3:8$14)^{12}$ encapsulated by a first person singular prayer (3:2) and confession of trust (3:16-19a). ${ }^{13}$ A separate superscript (3:1a) and musical notations $(3: 1 b, 3 b, 9 b, 13 d \& 19 b)$ might be regarded as later additions. ${ }^{14}$ The study of Hiebert (1986:5980) serves as a typical example. He emphatically rejects the view that Habakkuk 3 can be described as either a lament or a vision (1986:81) ${ }^{15}$ and classifies the poem as a 'song of victory' (1986:82). ${ }^{16}$ Hiebert (1986:59) identifies the poetic device of inclusion as the major stylistic feature of the poem. Prominent features constituting the device of inclusion between 3:2 and 3:16-19 are the occurrence of the verb רמעתי (3:2a, 16a) and the repetition of the root (3:2d, 16a, 16c; cf. Hiebert 1986:64). Habakkuk 3:16 is an intensification of 3:2, especially of the motif of fear present in 3:2a. Both sections are written from a first person perspective (Hiebert 1986:65). Habakkuk 3:17 should not be regarded as a later addition, but as an expansion of the motif of ברגז 'in turmoil' in 3:2. ${ }^{17}$ In similar fashion 3:18-19 complements the content of 3:2 by the prominent occurrence of the divine name יהוה (cf. 3:2a, 18a, 19a) and first person singular verbal forms (Hiebert 1986:67). Two stanzas can be demarcated in the theophany in 3:3-15. Habakkuk 3:3-7 describes the appearance of God from the southeast and nature's response to the appearance by means of third person verbal forms (Hiebert 1986:71). The unit has a 'perfect cyclic, inclusive structure' (Hiebert 1986:69) ${ }^{18}$ with geographical names forming the framework for the description of God's theophany (cf. 3:3 and 7). Habakkuk 3:8-15 describes the preparation of the divine warrior for battle and the battle itself (Hiebert 1986:73), this time by utilising second person verbal forms (Hiebert 1986:75). Again inclusion is present via the repetition of ים 'sea' and סוסיך 'your horses' (cf. 3:8 \& 15). ${ }^{19}$

Three recent studies on Habakkuk, all approaching the book from a literary perspective, have a slightly different view of the poem's structure. ${ }^{20}$ Andersen (2001:261-264) ${ }^{21}$ identifies

12.cf. Kaiser (1992:178).

13.Cf. Kaiser (1992:190).

14.I expressed similar views in previous publications (Prinsloo 1999:525-526, 2001:478-483, 2002:98-102). Research in the field of Unit Delimitation convinced me to propose an 'alternative' view on the text in this study. I already hinted at the possibilities of such an alternative reading (Prinsloo 2009:217-218).

15.Cf. Hiebert (1986:119-120).

16. Hiebert (1986:118) defines it as 'a song celebrating an Israelite military victory as triumph of Yahweh, the divine warrior.' The same genre is present in a number of songs dating from Israel's early history, notably Exodus 15:1-18, Judges 5 , of songs dating from Israel's early histor
Deuteronomy 33:2-5, 26-29 and Psalm 68.

17. Hiebert (1986:111-115) points to the alternation of perfect and imperfect forms characteristic of the poem as well as the presence of chiastic patterns to explain his reading of 3:17 as an expansion of 3:2. References to images from nature in this verse should be regarded as part of the devastating influence of YHWH's theophany.

18.For the detailed discussion of repetitive motifs, cf. Hiebert (1986:69-70).

19.Achtemeier (1986:53-60) identifies the following units: $3: 2 ; 3: 3-15 ; 3: 16 ; 17-19$. She considers the possibility that 3:16 might have been displaced and should be read together with 3:2 (Achtemeier 1986:54). According to her Habakkuk 3 then consists of an autobiographical framework (3:2 and 16) encapsulating a hymn (3:3the chapter has been used independently in the cult at some stage.

20.Cf. also Bliese (1999:62-66) who identifies seven 'poems' in Habakkuk 3 (3:2; 3:34; 3:5-6; 3:7-13a; 3:13b-14; 3:15-16; 3:17-19).

21.Cf. also Andersen's translation of Habakkuk 3 (2001:6-8). 
seven units. A title (3:1) and colophon (3:19b) frames a poem consisting of five strophes. An opening invocation (3:2) and closing response (3:16-19a) 'are more personal and more subjective' (Andersen 2001:261) and frame a theophany (3:3-15) that can be divided into three strophes. The 'first account of mighty deliverance (vv. 3-7) is a recital in the third person,' has the Exodus as historical background, but the 'stage is cosmic in its expanse' (Andersen 2001:261). 'In the middle strophe (vv. 8-11), the mode of address changes to apostrophe in the second person' and is concerned with YHWH's combat with 'cosmic elements,' evoking 'memories of stories of creation, but also of the Exodus and the battles of the early days' (Andersen 2001:262). 'In the third strophe (vv. 12-15) God is involved in history. The setting is the world (v. 12); the purpose is deliverance (v. 13); the enemy (unnamed) is almost represented as an individual (v. 14)' (Andersen 2001:262).

Nogalski (2011) classifies Habakkuk 3 as 'a theophany report put into the framework of a prayer and a prophetic affirmation of trust' and argues that the:

passage divides readily into four parts: Habakkuk's second superscription (3:1); a prophetic prayer and theophany report of God's advance from the south (3:2-7); a theophany regaling YHWH for his victory over chaos (3:8-15); and a prophetic response (3:16-19). (p. 679)

Nogalski thus combines 3:2 and 3:3-7 into a single strophe, but still retains the form critical distinction between 'theophany' (3:8-15) and 'prophetic response' (3:16-19).

Mathews (2012:85) engages in a 'performance approach' to the book of Habakkuk and consequently provides a 'dramatic division of the book of Habakkuk into acts and scenes'. Following many modern commentators, ${ }^{22}$ she classifies Habakkuk 3 as the second major part in the book ('Act Two - Faith') consisting of a 'prelude' (3:1) and 'postlude' (3:19b). She maintains the traditional division of the poem proper into three major parts $(3: 2 ; 3: 3-15 ; 3: 16-19 a)$ in her identification of 'Scenes'. She admits that her division is 'in fact similar to many literary divisions made by commentators.'

The brief overview illustrates the consensus amongst modern interpreters as far as the basic building blocks of Habakkuk 3 are concerned. It also confirms the initial observation that the consensus is based upon the form critical classification of material in the text.

\section{The structure of Habakkuk 3: Ancient perspectives}

\section{General orientation}

Careful analysis of a number of ancient Hebrew and Greek manuscripts, especially in the intertestamental and early medieval tradition, reveals a different understanding of the structure of Habakkuk 3. It is clear when ancient paragraph markers (petuchot and setumot) are taken into account. Noteworthy is the fact that the units demarcated by the ancient scribes transcend the form critical 'borders' set by modern interpreters. Ancient scribes evidently had a different approach to Habakkuk 3.

\section{The Greek Minor Prophets from Nahal Hever}

The Greek Minor Prophets scroll found in a cave in Nahal Hever (8HevXIIgr; cf. Tov 1990) dates from the middle of the first century $\mathrm{BCE}^{23}$ and was probably written for Jewish readers (Oesch 1979:304). Unfortunately the text is fragmentary. In the case of Habakkuk 3 petuchot can be identified with certainty before 3:1 and 3:14. The Greek scroll by and large agrees with the Masoretic tradition.

\section{The Twelve Prophets Scroll from Wadi Murabba 'at}

The Twelve Prophets' scroll from Wadi Murabba 'at (Mur88; cf. Benoit, Milik \& De Vaux 1961:199-200 and Plates LXVIIILXVIX) dates from circa 135 CE. ${ }^{24}$ The fragmentary state of the text makes reconstruction of all the petuchot and/or setumot once present in the Book of Habakkuk impossible. In the case of Habakkuk 3, though, setumot occur before 3:1; 3:8 and 3:14. In this respect Mur88 agrees with the Masoretic tradition. ${ }^{25}$ As will be agued in the next section it has important implications for the delimitation of units in and the interpretation of Habakkuk 3.

\section{Masoretic Manuscripts and the Biblia Rabbinica}

Comparison of a sample of Masoretic manuscripts confirms that ancient Jewish tradition had a different conception of the structure of Habakkuk 3. Although the tradition is not unanimous, ${ }^{26}$ a clear picture of their understanding of the structure of Habakkuk 3 emerges (cf. Table 1):

TABLE 1: Open and closed sections in Habakkuk 3 in a sample of Jewish manuscripts.

\begin{tabular}{lllllll}
\hline Before & CL & CP & CA & CC & CUrb & BibR \\
\hline $3: 1$ & $D$ & 0 & 0 & 0 & 0 & 0 \\
$3: 8$ & 0 & - & - & 0 & 0 & 0 \\
$3: 14$ & $D$ & 0 & 0 & 0 & 0 & 0 \\
\hline
\end{tabular}

CL, Pentateuch, Prophets and Hagiographa: Codex Leningrad B 194 (1970): the oldest complete Ben Asher manuscript of the Hebrew Bible. According to the colophon it was completed in $1008-1009$ CE.

CP, Codex Petropolitanus (1876): dates from 916 CE and contains Isaiah, Jeremiah, Ezekiel CP, Codex Petropolitanus (1876)
and the Book of the Twelve.

CA, Aleppo Codex (1976): the manuscript dates from 925 CE. It is regarded by many as the most valuable Ben Asher manuscript (cf. the discussion in Deist 1988:60-61).

CC, Codex Cairo of the Bible (1976). According to the colophon it was written down and punctuated by Moshe ben Asher in 895 CE. It contains the Former and Latter Prophets. Curb, Vatican Ms. Urbinati 2 (1979): according to the colophon the manuscript was written in $979 \mathrm{CE}$, but the colophon has been proven to be a forgery. The manuscript is probably from Italian origin and dates from the 14 th century CE.

BibR, Biblia Rabbinica (1972): a reprint of the 1525 Venice Edition edited by Jacob ben Hayim ibn Adoniya and originally printed by the famous printing house of Daniel Bomberg. Compared to the written manuscripts the printed edition contains more spaces, for example compll sped thes after almost every verse, sometimes larger spaces between some verses (e. small spaces after almost every verse, sometimes larger spaces between some verses (e.g. units are concerned, the Biblia Rabbinica agrees with the written codices.

23.Cf. the discussion in Fuller (1999:87-88) and García Martínez (2004:103-106)

24.Cf. the discussion in García-Martínez (2004:105-106).

25.Oesch (1979:288) indicates that in the case of the Twelve Prophets Mur88 by and large agrees with the Masoretic tradition with one exception. It has an open space before Haggai 3:14 not attested in any of the Masoretic codices.

26.It should come as no surprise. During the long process of the transmission of texts scribes made mistakes (Korpel 2000:5-6). Furthermore allowances should be made for the personal preference of individual scribes. Tov (2000:324) remarks: '... scribes must have felt free to change the sense divisions of th' add new ones in accord with their understanding of the context.' Oesch (1979:363) concludes that petuchot and/or setumot were transmitted with greater care in the Torah than in the rest of the books. 
From Table 1 it is clear that there are variations as far as the location of delimiters is concerned. In CP and CA no delimiter occurs before 3:8. There are also variations as far as the type of delimiter is concerned. Before 3:1 CL has a petuchah whilst the other manuscripts have a setumah. Before 3:8 CUrb has a petuchah whilst CL, CC and BibR have a setumah. Before 3:14 CL, CP and CUrb have a petucah whilst CA, CC and BibR have a setumah. Nevertheless, the location of the paragraph markers indicates that ancient Masoretic scribes demarcated two (3:1-13 and 3:14-19; cf. CP, CA) or three (3:1-7; 3:8-13; 3:14-19; cf. CL, CC, CUrb, BibR) units in the chapter. It defies the modern form critical demarcation of four units.

The petuchot and/or setumot in Habakkuk 3 demarcate large textual units that can be subdivided into smaller units. ${ }^{27}$ Noteworthy is the fact that the boundaries of the three sections differ from the traditional demarcation of sections in modern commentaries and other studies. Unit delimitation in the ancient manuscripts under discussion poses serious questions to the traditional interpretation of Habakkuk 3.

In Addendum 1 I provide the text of Habakkuk 3, a parallel translation and criteria for unit delimitation. ${ }^{28}$ Data in ancient Hebrew manuscripts suggest that three major sections can be demarcated in Habakkuk 3, namely 3:1-7; 3:8-13 and 3:14-19. Corroborative data in manuscripts of the Septuagint indicate that $3: 1 \mathrm{ab}$ can be demarcated as a superscript..$^{29}$ It displays the characteristics of a typical 'superscript' in the Psalter. ${ }^{30}$ Habakkuk 3:19d is more problematic. The phrase למנצח בנגנותי has parallels in superscripts in the Book of Psalms, ${ }^{31}$ but it never appears as a subscript in the Psalter. The Septuagint (followed by the other ancient versions) did not understand $3: 19 \mathrm{~d}$ as a subscript, but read it in conjunction with $19 \mathrm{c} .{ }^{32}$

In the light of ancient unit delimiters the following sections can be demarcated (cf. Table 2):

TABLE 2: Major sections in Habakkuk 3.

\begin{tabular}{lll}
\hline Section & Verses & Content \\
\hline 1 & $3: 1$ & Superscript \\
2 & $3: 2-7$ & God's awe-inspiring manifestation \\
3 & $3: 8-13$ & Indignant anger... salvation for your people \\
4 & $3: 14-19 d$ & Destroying the enemy, worthy of my trust \\
5 & $3: 19 d$ & Subscript \\
\hline
\end{tabular}

27.For corroborative evidence four manuscripts of the Septuagint have been consulted. All agree that a new section begins at $3: 1$. In Codex Alexandrinus (1936)
and Codex Vaticanus (1907) the transition between 2:20b and 3:1a is marked by a and Codex Vaticanus (1907) the transition between 2:20b and 3:1a is marked by a
line left open and in Codex Sinaiticus (1922) by a double dot. All four manuscripts line left open and in Codex Sinaiticus (1922) by a double dot. All four manuscripts also write 3:1ab as a separate superscript. Codex Alexandrinus (1936) and Codex
Sinaiticus (1922) mark 3:2a as the beginning of a new section by a 'large' letter and Sinaiticus (1922) mark 3:2a as the beginning of a new section by a 'large' letter and
ekthesis respectively. In both Codex Alexandrinus (1936) and Codex Marchalianus (1890) Habakkuk 3 is written 'stichometrically' (every colon begins on a new line in Codex Alexandrinus marked with a 'large' letter). In Codex Vaticanus (1907) and Codex Sinaiticus (1922) the subdivisions of Habakkuk 3 are determined by the occurrence of in the Hebrew text (cf. 3:3b, 9b, 13d). Greek by $\delta$ ió $\psi \alpha \lambda \mu \alpha$. In each case it is written in the middle of the column, thus dividing Habakkuk 3 into five sections (3:1ab; $2 a-3 b ; 3 c-9 b ; 9 c-13 d ; 14 a-19 d$ ).

28.It falls outside the scope of this paper to discuss the text critical difficulties in the text. Major problems have been discussed elsewhere (cf. Prinsloo 2002:88-98).

29.Cf. the remarks in the previous note.

30.Cf. Psalms $6: 1 ; 8: 1 ; 9: 1 ; 12: 1 ; 22: 1 ; 45: 1 ; 46: 1 ; 53: 1 ; 56: 1 ; 62: 1 ; 69: 1 ; 77: 1 ; 81: 1$.

31.Cf. Psalms $4: 1 ; 6: 1 ; 54: 1 ; 55: 1 ; 67: 1 ; 76: 1$.

32.Cf. the discussion in note 35 of the Addendum.

\section{Structural patterns and dominant motifs in תפלה Habakkuk's}

Ancient scribal practices suggest a delimitation of sections with important implications for the interpretation of the text. Contra form critical arguments for the demarcation of two petitions $(3: 2 ; 3: 16-19)$ framing a theophany in two parts (3:3-7; 3:8-15), ancient scribes read Habakkuk 3 as a single תפלה 'prayer.' ${ }^{\prime 33}$ Read through their eyes three important characteristics of the text should be noted.

\section{Inclusio as dominant structural pattern}

The importance of inclusio as poetic strategy in Habakkuk 3 has been recognised in the overview of existing approaches to Habakkuk 3. When delimitation criteria in ancient manuscripts are taken as point of departure, the phenomenon becomes the dominant textual strategy in the poem.

Section 1 (3:1) and Section 5 (3:19c), a superscript and subscript respectively, frame the poem proper. Both contain information typical of the superscripts in the Book of Psalms. The phrase תפלה ל... 'a prayer of ...' occurs elsewhere only in superscripts to psalms. תפלה 'prayer' characterises the content of the poem in a special manner and includes the whole chapter in the classification. The 'author' of the prayer is called חבקוק הנביא 'Habakkuk the prophet.' ${ }^{\prime 35}$ The following על שגינות 'on 'Shigyonoth' (1b) is reminiscent of psalm superscripts with a note about the poem's melody and/or accompanying musical instrument. שגינות is a hapax legomenon, often regarded as the plural of שגיות (cf. Ps 7:1). Many associate it with the Akkadian noun šig $\hat{u}$ 'cry of lamentation,' and regard it as an indication of the poem's genre, and consequently classify Habakkuk 3 as a lament (Van der Woude 1978:60). ${ }^{37}$ However, the combination + noun in psalm superscripts are not associated with the poem's genre and the content of Habakkuk 3 hardly lends itself to be classified as a lament (Roberts 1991:130). The exact intent of למנצח בנגינותי 'to the conductor, on my stringed instruments' in 3:19d remains an enigma. Similar phrases are known from the Psalter, but always in superscripts. ${ }^{38}$ It is a

33.The purpose of the present study is not to provide a detailed exegetical analysis of Habakkuk 3. In two earlier studies (Prinsloo 2001, 2002) I engaged in more detailed exegetical analysis, albeit within the framework of the 'traditional' demarcation of units. In a recent publication (Prinsloo 2013) I provide a brief exegetical analysis of Habakkuk 3 following the demarcation of units proposed in the current study.

34.Cf. Psalms 17:1; 86:1; 90:1; 102:1. Andersen (2001:268) remarks: 'The term těpillâ is a general word for prayer. It appears ... in the title of several psalms, most of which represent personal supplications in times of distress.'

35.Cf. Habakkuk 1:1. Exegetes should honestly acknowledge that this is all that can be said about the prophet (Huwyler 2001:248, n. 56) Cf. Sweeney (1992:1-2) and Nogalski (2011:645-649) for speculations about Habakkuk's identity in Jewish Nogalski

36.Cf. Psalms 6:1; 12:1 (על־השמינית 'upon an eight-string lyre'); 8:1; 81:1; 84:1

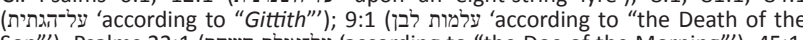
Son"'); Psalms 22:1 (על על עילת השחר 'according to "the Doe of the Morning"'); 45:1;

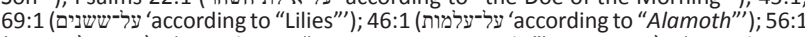

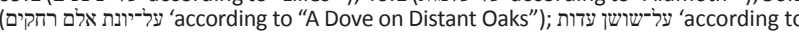
"The Lily of the Covenant"); $61: 1$ (על-נגינת 'upon stringed instruments'); 62:1; 77:1 (עלידותון 'according to "Jeduthun"); 88:1 (על־מהלת לענות 'according to "Mahalath Leannoth"'). For the difficulties in the interpretation of these terms see the discussion ad loci by Hossfeld and Zenger $(1993,2005)$.

37.Cf. Andersen (2001:268-273) for a critical discussion of the alleged relationship between שגינות and various possible derivates of the Akkadian root šegû.

38. למנצה 'to the conductor' occurs in 55 psalm superscripts and only in Habakkuk 3:19d outside the Psalter. For the difficulties in the interpretation of the term, cf. Hossfeld and Zenger (1993:60). בנגינות 'with stringed instruments' occurs in seven psalm superscripts, always following directly upon למנצה (cf. Psalms 4:1; 6:1; 54:1; 
liturgical notation, but its exact implication is no longer clear to modern readers. ${ }^{39}$

In spite of uncertainties regarding the interpretation of individual words, the notion that Habakkuk 3:1 classifies the content of the entire chapter as a תפלה should be taken seriously. In psalm superscripts the content of a תפלה carries undertones of thankfulness, joy and trust in spite of dire circumstances (Bratcher 1985:226-227). In its current literary context Habakkuk 3:1 marks a change in the mood of the book from 1:1's המשא with its undertones of prophetic protest and divine response in Habakkuk 1-2 to unconditional trust and faithful devotion in Habakkuk 3 (Prinsloo 1999:520).

The three sections of the poem proper (2 [3:2-7]; 3 [3:8-13]; 4 [3:14-19]) are characterised by elaborate inclusios. In Section 2 (3:2-7) 1 singular qtl verbal forms in 2a (שמעתי 'I heard'; יראתי 'I feared') and 7a (ראית' I saw') constitute the first inclusio and frame the observation of God's appearance from the southeast, described in 3:3-7. The object of the verbs in 2a is God's 'repute' (שמעך) and his 'work' (פעלך), whilst the object of the verb in 7ab is the 'tents of Kushan' (אהלי כושן) and the 'tent curtains of the land of Midian' (יריעות ארץ מדין) - and they are 'under iniquity' (תחת און) and 'trembling' (ירגזון). Careful observation of God's triumphant march from the south-east leads to a change in the perspective of the poet, from the 'turmoil' (רגז [2d]) he is experiencing to the 'trembling' (ירגזון [7b]) of the dwelling places of the enemy. The repetition of the root רגin in $2 \mathrm{~d}$ and $7 \mathrm{~b}$ constitutes a second inclusio. Reference to place names associated with the south-eastern regions of Palestine in 3:3 and 3:7 constitutes a third inclusio:

\begin{tabular}{|c|c|}
\hline אלוה מתימן יבוא & 3a God comes from Teman, \\
\hline וקדוש מהר־פארן & 3b the Holy One from the mountain of Paran. \\
\hline תחת און ראיתי אהלי כושן & Under iniquity I see the tents of Kushan, \\
\hline ירגזו יריעות ן ארץ מדין & $\begin{array}{l}\text { 7b they are trembling, the tent curtains of } \\
\text { the land Midian. }\end{array}$ \\
\hline
\end{tabular}

A fourth inclusio is constituted by temporal phrases in 3:2 and 3:6. The phrase בקרב שנים 'in the midst of years' occurs twice in an urgent prayer (cf. 3:2bc). God should 'call to life' (תייהו) and 'make known' (תודיע) his 'repute' and 'work' (cf. $3: 2 \mathrm{~cd}$ ). The poet heard about it and feared (cf. 3:2a), but he does not observe it in the reality of his present circumstances. By recalling God's mighty appearance from the south-east as warrior (3:3) clouded in brilliant light (3:4) amongst his heavenly retinue (3:5), and especially by recalling it as עולם לו הליכות 'age-old ways for him' (6e), the poet actualises God's mighty deeds of the past in the present. God's 'age-old ways' stand in sharp contrast to the temporary dwellings of the enemy in 7ab - the 'tents of Kushan' and the 'tent curtains of the land of Midian.'

(Footnote 38 continues ....)

$55: 1 ; 61: 1 ; 67: 1 ; 76: 1)$. A pronominal suffix is added only in Habakkuk $3: 19 \mathrm{~d}$ Andersen (2001:350) suggests the translation 'for the conductor in my string ensemble.

39.Nogalski (2011:681) points to the fact that the liturgical notations in Habakkuk 3:1 and $19 \mathrm{~d}$ show similarities with superscripts predominantly present in Books I-III of

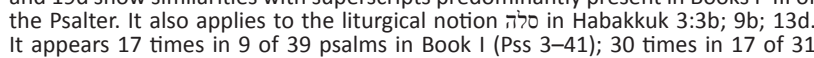
It appears 17 times in 9 of 39 psalms in Book I (Pss 3-41); 30 times in 17 of 31
psalms in Book II (Pss 42-72); 20 times in 11 of 17 psalms in Book III (Pss 73-89); psalms in Book II (Pss 42-72); 20 times in 11 of 17 psalms in Book III (Pss 73-89); it is absent in Book IV (Pss 90-106) and appears only 4 times in 2 of 39 psalms in
Book V (Pss 107-145). The majority of occurrences are thus in Books I-III, with the Book V (Pss 107-145). The majo
highest frequency in Book III.
Section 3 (3:8-13) is characterised by the following inclusios: The first inclusio is constituted by the repetition of the root in 3:8 and 3:13. The similarity between the actions of YHWH described in 3:8 and 3:12-13 constitutes a second inclusio. Apart from 'salvation,' 3:8 contains two other motifs, namely 'anger' and 'riding upon:'

\begin{tabular}{|c|c|c|}
\hline הבנהרים חרה יהוה & $8 \mathrm{a}$ & Does it burn against the rivers, $Y H W H$, \\
\hline אם בנהרים אפך & $8 b$ & is your anger toward the rivers, \\
\hline אם־בים עברתך & $8 c$ & is your wrath toward the sea, \\
\hline כי תרכב על־סוסיך & $8 \mathrm{c}$ & that you ride on your horses, \\
\hline מרכבתיך ישועה & $8 d$ & your chariots of salvation? \\
\hline
\end{tabular}

Habakkuk 3:12 repeats the motif of 'anger' and 'trampling upon' and 3:13 answers the rhetorical questions of 3:8 - the actual purpose of YHWH's coming is the 'salvation' of his people and the destruction of the wicked:

\begin{tabular}{|c|c|}
\hline 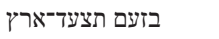 & 12a In indignation you trample the earth, \\
\hline באף תדוש גוים & $12 \mathrm{~b}$ in wrath you thresh the nations. \\
\hline יצאת לישע עמך & $\begin{array}{l}\text { 13a You go forth for the salvation of you } \\
\text { people, }\end{array}$ \\
\hline לישע את־משיחך & $13 \mathrm{~b}$ for the salvation of your anointed. \\
\hline מחצת ראש מבית רשע & $\begin{array}{l}\text { 13c you shatter the head of the house of the } \\
\text { wicked, }\end{array}$ \\
\hline ערות יסוד עד־צואר & $13 \mathrm{~d}$ to lay bare the foundation to the neck. \\
\hline
\end{tabular}

A third inclusio is constituded by the repetition of the noun in 3:9 and 12. In 3:9 YHWH 'cleaves the earth with rivers' and in 3:12 he tramples 'the earth in indignation.' YHWH's acts of salvation thus have an effect upon and become apparent on earth.

Section 4 (3:14-19) is characterised by two inclusios. The first is constituted by the 1 singular pronominal suffix in 3:14 and five 1 singular suffixes in 3:19:

14a You pierce with his own weapons the
head of his warriors,
14b while they storm to scatter me,
14c their rejoicing as one who devours the
poor in hiding.
19a YHWH my Lord is my strength,
19b he makes my feet like those of the hinds,
19c on my high places he makes me walk.

The contrast between the situation of the prophet in 3:14 and 19 is especially apparent in this inclusio. A second inclusio is formed by the 1 singular verbs and suffixes in 3:16 and 18, all again framed by the 1 singular suffixes in 3:14 and 19:

\begin{tabular}{|c|c|}
\hline 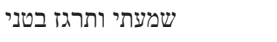 & 16a I heard and my body trembled, \\
\hline לקול צללו שפתי & $16 \mathrm{~b}$ at the sound my lips quivered, \\
\hline יבוא רקב בעצמי ותחתי ארגז & $\begin{array}{l}\text { 16c rottenness enters into my bones and } \\
\text { beneath me I tremble }\end{array}$ \\
\hline אשר אנוח ליום צרה & 16d where I wait for the day of distress \\
\hline לעלות לעם יגודנו & $\begin{array}{l}\text { 16e to come for the people who are attacking } \\
\qquad \text { us. }^{40}\end{array}$ \\
\hline ואני ביהוה אעלוזה & 18a Yet I will exult in YHWH, \\
\hline 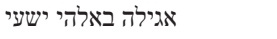 & $18 \mathrm{~b}$ I will rejoice in the God of my \\
\hline
\end{tabular}

Again the contrast between the situation of the prophet in $3: 16$ and 18 is emphasised by the inclusio.

40.The single occurrence of a 1 plural pronominal suffix in the entire poem points to עני במסתר as poet being a representative for a group of people, identified in 3:14c as 'the poor in hiding'. 
Inclusio is a dominant feature in the overall structure of the poem. It is especially apparent in the repetition of the verbal form שמעתי 'I heard' in Section 2 (3:2a) and Section 4 (3:16a) and the repetition of the root רגת in Section 2 (ברגז 'in turmoil' in 3:2d; ירגזון 'they are trembling' in 7b) and Section 4 (בטני ארגז 'my body trembled' in 3:16a; 'I tremble' in 3:16c).

\section{Communication patterns}

If Habakkuk 3 is read as a single הלפת an interesting pattern in the text's flow of communication becomes discernible. In Section 2 (3:2-7) there is a 'two-way' and 'mixed' communication pattern. In the introductory prayer $(3: 2)$, the pattern is 'I $\rightarrow$ you': two 1 singular $q t l$ verbal forms introduce the section, ${ }^{41}$ whilst no less than five 2 masculine singular forms are used in the prophet's direct address to YHWH. ${ }^{42} \mathrm{In}$ the description of God's triumphant march from the southeast (3:3-7) the communication pattern is 'he $\rightarrow$ I' with strong emphasis on 3 masculine singular forms referring to God. $\mathrm{He}$ is the subject of five verbal forms and eight 3 masculine singular suffixes also refer to him. ${ }^{43}$ A single 1 singular verbal form (ראיתי 'I see' in 7a) involves the poet in the awesome appearance of $\mathrm{YHWH}$ from the south-east and recalls the 1 singular forms in the introductory prayer, thus framing the third person description of God's 'coming' in 3:3-6.

In Section 3 (3:8-13) the communication pattern is 'one-way' and 'singular.' The focus is entirely on YHWH's actions and the effect it has upon creation and the description is entirely in the second person. It is illustrated by seven 2 masculine singular verbal forms and ten 2 masculine singular pronominal suffixes. ${ }^{44}$ This 'singular' pattern, framed by two sections with a 'mixed' pattern, ensures that 3:8-13 receives special emphasis. ${ }^{45}$

In Section 4 (3:14-19) the flow of communication is again 'two-way' and 'mixed.' In a short introductory description of YHWH's attack on the enemy (3:14-15) the flow of communication is 'you $\rightarrow \mathrm{I}$ ': YHWH's actions against his enemies are described by means of two 2 masculine singular verbs and one 2 masculine singular pronominal suffix. ${ }^{46}$ The actions of the enemies are directed against the poet, referred to by means of a 1 singular pronominal suffix (להפיצני 'to scatter $\mathrm{me}^{\prime}$ in 14b). This introductory section is reminiscent of the opening prayer (3:2) and of the 2 masculine singular forms in Section 3 (3:8-13). In the longer prayer and expression of confidence (3:16-19) the flow of communication is ' $\mathrm{I} \rightarrow$

41.Cf. שמעתי (2a);

42.Two pronominal suffixes, cf. שמעך (2a); פעלך (2b) and three modal forms, cf. חייד (2b) (2b); תודיע (2c); (2d).

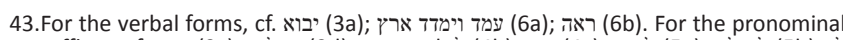

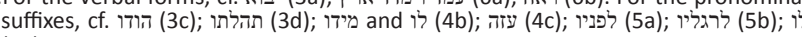
(6e).

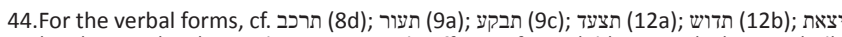
(13a); מחצת (13c). For the pronominal suffixes, cf. אפר (8b); עברתך (8c); סוסרך (8d);

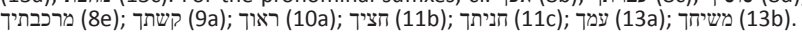

45.The second person forms of course imply the involvement of the poet, but as a mere spectator, a reporter on the events transpiring before him. Mathews $(2012: 151)$ remarks that the poet 'does not express his emotions but merely reports the events.'

46.For the verbal forms, cf. נקבת (14a); דרכת (15a). For the pronominal suffix, cf. סוסיך (15a) he' with emphasis upon the poet's reaction upon YHWH's victory over the wicked. It is expressed by means of five 1 singular verbal forms, ten 1 singular pronominal suffixes and one 1 singular independent personal pronoun. ${ }^{47}$ Twice a positive action of $\mathrm{YHWH}$ towards the poet is mentioned by means of 3 masculine singular verbal forms. ${ }^{48}$ Thus 3:16-19 is reminiscent of the communication pattern in 3:3-7, there with emphasis on YHWH's action, here with emphasis upon the poet's reaction.

Communication patterns in Habakkuk 3 enhance the dominant occurrence of inclusio in the poem in general and it's various building blocks in particular. In 3:2 and 3:8-15 YHWH is addressed directly in the second person, whilst he is addressed indirectly in the thirrd person in 3:3-6 and 3:16-19, thus creating an $a b a b$ pattern in addressing $\mathrm{YHWH}$ or God in the poem. However, first person forms referring to the poet, transforms the parallel pattern in addressing YHWH to an intricate chiastic pattern framing 3:8-13. Section $2(3: 2-7)$ is framed by 1 singular forms in 3:2a and 3:7a. Section 4 (3:14-19) is framed by 1 singular forms in 3:14b, 3:16 and 3:18-19. In Section 2 the 1 singular forms frame a short prayer addressed to $\mathrm{YHWH}$ in the second person (3:2bcd) and a long description of God's triumphant march from the south-eastern desert (3:2-6). In Section 4 the 1 singular suffix in 3:14b links up with the 1 singular verb in 3:7a. In 3:7 the poet 'sees' the dwelling of the enemy 'under iniquity' and 'trembling'. In 3:14 the enemy is destroyed by YHWH as they 'storm to scatter me,' whilst the first person forms in 3:16 and 18 express a confession in the ultimate power of YHWH framing 3:17, expressing the most dire and precarious living conditions. Section 3 is the only section without any first person references, the only section exclusively reserved for 2 masculine singular forms referring to $\mathrm{YHWH}$, and the section where it becomes clear that $\mathrm{YHWH}$ and his retinue (3:2-6) is actually marching from the south-east to destroy the enemies of his people. Habakkuk 3:8-13 thus becomes the heart of the poem, culminating in the complete destruction of the wicked in 3:13.

\section{YHWH the warrior and personal prayer or confession as focal points}

If Habakkuk 3 is read as a single תפלה the motif of YHWH as warrior becomes the dominant focal point present in all three main sections of the poem, ${ }^{49}$ whilst first person prayer and/or confession becomes a second focal point in 3:2-7 and $3: 14-19$. In 3:2-7 the prayer motif is present in the poet's urgent prayer that YHWH's 'fame' and 'work' should be made a reality in his present dire circumstances. The poet proceeds to do just that when he recalls the great theophany of God in the south-eastern desert when Israel was born as a nation (3:3-7). Habakkuk 3:7 makes it clear, though, that the poet is involved in reminiscing this salvific appearance

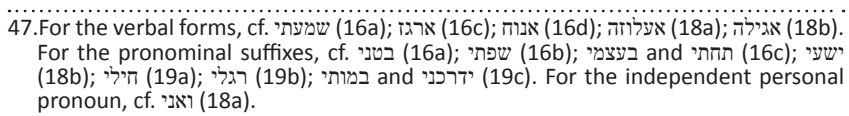

49.Cf. Miller (2006) and Pfeiffer (2005) for detailed discussions of the motif. 
of God in the distant past, because he 'saw' the dwelling places of Israel's enemies 'under iniquity' and 'trembling,' remembering God's theophany at Sinai as his 'age old ways' (3:6e). It is God's 'nature' to get into motion, to travel his הליכות עולם when his people are in trouble. Inclusio and communication patterns artfully create two focal points in 3:2-7. The framing of God's triumphant appearance from the south-east (3:3-6) enhances the dominant motif of God as warrior. The first person singular frame (3:2 and 7) at the same time focuses attention on the poet's present plight, urgent prayer, and certainty that ultimately God's הליכות עולם is the guarantee that his people will be saved again.

In 3:8-13 the motif of $\mathrm{YHWH}$ as warrior becomes a clear reality in a direct address, an eyewitness report of YHWH's triumphant victory over the wicked. The poet disappears into the background and YHWH and his great salvific deeds are described in the second person. Here a frame is created by rhetorical questions in 3:8 and the clear answer to the questions in 3:12-13 - YHWH's anger is directed against the רשית רשע רשית 'the head of the wicked house' (3:13c) and his intervention is ultimately, aimed that the salvation of his people. The centre (3:9-11) confirms YHWH's victory over all powers of chaos past and present (Nogalski 2011:685).

In 3:14-19 the theophany motif is briefly present in 3:14-15, again as an eyewitness report referring to YHWH's deeds in the second person. Habakkuk 3:14-15 links up with the mythological language in 3:8 with references to ים 'sea' (3:8c, 15a) and סוסיך 'your horses' (3:8d, 15a), thus ensuring a strong link between Sections 3 (3:8-13) and 4 (3:14-19). However, the first person motif of Section 2 returns in $3: 14 b$, where it becomes clear that the speaker is experiencing להפיצני 'to scatter me' and rejoicing כמו־לאכל עני במסתר 'as one who devours the poor in hiding' (3:14c). In those circumstances, as the poet recalls the triumphant march of God the warrior from the south-east (3:2-6) and the annihilation of the enemy by YHWH the warrior (3:8-13) בקרב שנים 'in the midst of years' $(3: 2 b, 2 c)$, urgent prayer evolves into a great confession of unconditional trust in $\mathrm{YHWH}$ in spite of dire living conditions (3:16-19).

\section{Conclusion}

Unit delimitation in ancient manuscripts prompts the interpreter to reconsider the traditional form critical approach to Habakkuk 3 (Prinsloo 2009:218). Ancient unit delimiters transcend the neat borders between units demarcated on form critical grounds and indicate that Habakkuk 3 can be read as a single prayer containing the dominant theme of $\mathrm{YHWH}$ the warrior, coupled with a second theme, namely the personal involvement of the poet in the events of his day, expressed by means of urgent prayer (3:2), careful observation (3:7), negative experience (3:14) and, in the end, deferential awe and joyful confidence in the presence of YHWH (3:16-19).

Reading Habakkuk 3 as a single תפלה has important implications for the interpretation of the poem in the context of the book of Habakkuk. In a previous publication (Prinsloo 2001) I focused on intertextual links between the poem and other hymnic passages in the Hebrew Bible (cf. Ex 15:1-18; Dt 33:1-3; Jdg 5:4-5; Pss 18:8-16; 68:8-9; 77:17-20; 144:5-6). I argued that 3:3-6 and 3:8-13, 15 might contain archaic hymnic passages incorporated by the poet in $3: 2,7,14,16$ 19 in a new composition. Theophanies hinting at the Sinai and exodus experiences of Israel's distant, mythical past are applied to the poet's present circumstances. The focus of the present study does not allow for a detailed exposition of this observation. Others, however, argued that the insertion of so-called 'ancient' hymnic passages in different contexts of the Hebrew Bible are indicative of the interpretation of surrounding material by later exegetes. Mathys (1994) remarks that:

mit den Psalmen, die sich am Ende von Prophetenbüchern finden, habe die Gemeinde auf deren Verlesung geantwortet... Das hieße auch, daß der Prozeß ihrer Kanonisierung eingesetzt hat ... Diese fassen die Bücher, in denen sie stehen, zusammen und interpretieren sie ... Interpretation, Verallgemeinerung, Zusammenfassung, Kanonisierung - dafür eignen sich Gebete, Psalmen und Doxologien in besonders ausgezeichneter Weise. (p. 318)

Reading Habakkuk 3 as a single תפלה hints at the possibility that this text can be interpreted as a later generation's appropriation of Habakkuk 1-2 into their present circumstances.

The reference to עני 'the poor' (3:14) and יגודנו 'who are attacking us' (3:16) points to the poet of Habakkuk 3 being a member of a specific social group in the late Persian and/ or early Hellenistic period who regarded themselves as the true Israel and as the actual recipients of YHWH's salvific intervention in and promises to his people. ${ }^{50}$ The poet appropriates $\mathrm{YHWH}^{\prime}$ s promise to the prophet Habakkuk at the time of the Chaldean onslaught on and devastation of Jerusalem to his own predicament as a marginalised 'poor' in a wicked and hostile environment. For him the:

Theophanie aus Edom/Seir wurzelt in der Vorstellung vom Jahwe-Gericht über Edom, die hier so verdichtet ist, dass 'Edom' nur noch als Chiffre für das Gericht verwendet wird ... Die Edom-Gerichts-Tradition ist bereits trandensiert. Jes 63, 1-6 liegt im Rücken. (Pfeiffer 2005:259-260) ${ }^{51}$

In Habakkuk 3 unit delimitation indeed 'calls for a profound re-evaluation' of the chapter's structure and 'the classification of sections and indeed the interpretation' of the pericope (Prinsloo 2009:219).

\section{Acknowledgements Competing interests}

The author declares that he has no financial or personal relationship(s) which may have inappropriately influenced him in writing this article.

50.Cf. Ro (2002) for a detailed discussion of this movement. Cf. also Levin (2003, esp 331-333)

51.Cf. also Nogalski (2011:683) for a discussion of possible intertextual links between Habakkuk 3 and the anti-Edom utterances in Isaiah 34:5-7 and 63:1-6. 


\section{References}

Achtemeier, E., 1986, Nahum - Malachi, John Knox, Atlanta. (Interpretation).

Albertz, R., 2003, 'Exilische Heilsversicherung im Habakukbuch', in K. Kiesow \& T. Meurer (Hrsg.), Textarbeit. Studien zu Texten und ihrer Rezeption aus dem Alten Testament und der Umwelt Israels. Festschrift für Peter Weimar zur Vollendung Testament und der Umwelt Israels. Festschrift für Peter Weimar zur Vollendung seines 60. Lebensjahres mit Beiträgen von Freunden, Schülern uns Kolle
1-20, Ugarit-Verlag, Münster. (Alter Orient und Altes Testament, 294).

Aleppo Codex, 1976, Aleppo Codex: Provided with massoretic notes and pointed by Aaron Ben Asher, Makor, Jerusalem. (The Hebrew University Bible Project).

Andersen, F.I., 2001, Habakkuk, Doubleday, New York/London. (Anchor Bible, 25).

Avishur, Y., 1994, 'Habakkuk 3', in Y. Avishur (ed.), Studies in Hebrew and Ugaritic Psalms, pp. 111-205, Magnes, Jerusalem.

Benoit, P., Milik, J.T. \& De Vaux, R., 1961, Les Grottes de Murabba'ât, Clarendon, Oxford. (Discoveries in the Judean Desert, II).

Biblia Rabbinica, 1972, Biblia Rabbinica: A reprint of the 1525 Venice Edition edited by Jacob ben Hayim ibn Adoniya, Makor, Jerusalem.

Bliese, L.F., 1999, 'The Poetics of Habakkuk', Journal of Translation and Textlinguistics $12,47-75$.

Bratcher, D.R., 1985, The theological message of Habakkuk: A literary-rhetorical analysis, Michigan University Microfilms, Ann Arbor.

Clark, D.J. \& Hatton, H.A., 1989, The Books of Nahum, Habakkuk, and Zephaniah United Bible Societies, New York. (United Bible Societies Handbook Series).

Codex Alexandrinus, 1936, The Codex Alexandrinus in reduced photographic facsimile Old Testament, Part III Hosea-Judith, F.G. Kenyon (ed.), British Museum, London.

Codex Cairo of the Bible, 1971, Codex Cairo of the Bible: From the Karaite Synagogue at Abbasiya: The earliest extant Hebrew manuscript written in 895 by Moshe ben Asher (Introduction by D.S. Lowinger), Makor, Jerusalem.

Codex Marchalianus, 1890, Prophetarum Codex Graecus Vaticanus 2125 Qui Dicitur Marchalianus, J. Cozza-Luzi (ed.), Bibliotheca Vaticana, Romae.

Codex Petropolitanus, 1876, Prophetarum Posteriorum Codex Babylonicus Petropolitanus, H. Strack (ed.), n.p., Petropoli.

Codex Sinaiticus, 1922, Codex Sinaiticus Petropolitanus et Friderico-Augustanus Lipsiensis: The Old Testament preserved in the public library of Petrograd, in the library of the Society of Ancient Literature in Petrograd, and in the library of the University of Leipzig now produced in facsimile from photographs by Helen and Kirsopp Lake, Clarendon, Oxford.

Codex Vaticanus, 1907, Bibliorum SS: Graecorum Codex Vaticanus 1209 (Cod. B) Denvo Phototypice Expressusliussu et Cura Praesidum Bybliothecae Vaticanae, Pars Prima Testamentum Vetus, Tomus III, Mediolani.

Dangl, O., 2001, 'Habakkuk in recent research', Currents in Research: Biblical Studies 9, 131-168.

De Hoop, R., 2002a, 'The colometry of Hebrew verse and the Masoretic accents: Evaluation of a recent approach (Part I)', Journal of North-West Semitic Languages 26, 47-73.

De Hoop, R., 2002b, 'The colometry of Hebrew verse and the Masoretic accents: Evaluation of a recent approach (Part II)', Journal of North-West Semitic Languages 26, 65-100.

Deist, F.E., 1988, Witnesses to the Old Testament: Introducing Old Testament Textual Criticism, NG Kerkboekhandel, Pretoria. (Literature of the Old Testament, 5).

Fuller, R., 1999, 'The text of the Twelve Minor Prophets', Currents in Research: Biblical Studies 7, 81-95.

García-Martínez, F., 2004, 'The text of the XII Prophets at Qumran', Old Testament Essays 17, 103-119.

Haak, R.D., 1992, Habakkuk, Brill, Leiden. (Supplements to Vetus Testamentum, XLIV).

Hiebert, T., 1986, God of my victory: The ancient hymn in Habakkuk 3, Scholars, Atlanta. (Harvard Semitic Monographs, 38).

Hossfeld, F-L. \& Zenger, E., 1993, Die Psalmen: Psalm 1-50, Echter, Würzburg. (Neue Echter Bibel, 29).

Hossfeld, F-L. \& Zenger, E., 2005, Psalms 2: A commentary on Psalms 51-100, transl. L.M. Maloney, Fortress, Minneapolis. (Hermeneia).

Huwyler, B., 2001, 'Habakuk und seine Psalmen', in B. Huwyler, H-P. Mathys \& B. Weber (Hrsg.), Prophetie und Psalmen: Festschrift für Klaus Seybold zum 65: Geburtstag, pp. 231-259, Ugarit-Verlag, Münster. (Alter Orient und Altes Testament, 280).

Kaiser, W.C., 1992, Micah-Malachi, Word Books, Dallas. (Communicator's Commentary)

Korpel, M.C.A., 2000, 'Introduction to the Series Pericope', in M.C.A. Korpel \& J.M Oesch (eds.), Delimitation criticism: A new tool in biblical scholarship, pp. 1-50, Assen, Van Gorcum, Assen. (Pericope 1).
Levin, C., 2003, Fortschreibungen: Gesammelte Studien zum Alten Testament, De Gruyter, Berlin/New York. (Beihefte zur Zeitschrift für die alttestamentliche Wissenschaft, 316).

Loader, J.A., 1979, Polar structures in the book of Qohelet, De Gruyter, Berlin. (Beihefte zur Zeitschrift für die alttestamentliche Wissenschaft, 152).

Markl, D., 2004, 'Hab 3 in intertextueller und kontextueller Sicht', Biblica 85, 99-108.

Mason, R., 1994, Zephaniah, Habakkuk, Joel, JSOT Press, Sheffield. (Old Testament Guides).

Mathys, H-P., 1994, Dichter und Beter: Theologen aus spätalttestamentlicher Zeit, Vandenhoeck \& Ruprecht, Göttingen. (Orbis Biblicus et Orientalis, 132).

Mathews, J., 2012, Performing Habakkuk: Faithful re-enactment in the midst of crisis, Pickwick, Eugene.

Miller, P.D., 2006, The divine warrior in Early Israel, SBL, Atlanta.

Nogalski, J.D., 2011, The Book of the Twelve: Micah-Malachi, Smyth \& Helwys, Macon. (Smyth \& Helwys Bible Commentary). PMid:21084488, PMCid:PMC3020497

Oesch, J.M., 1979, Petucha und Setuma: Untersuchungen zu einer überlieferten Gliederung im hebräischen Text des Alten Testaments, Vandenhoeck \& Ruprecht, Göttingen. (Orbis Biblicus et Orientalis, 27).

Patterson, R.D., 1987, 'The Psalm of Habakkuk', Grace Theological Journal 8, 163-94.

Pentateuch, Prophets and Hagiographa: Codex Leningrad B 194, 1970, Pentateuch, Prophets and Hagiographa: Codex Leningrad B 19A, Makor, Jerusalem.

Pfeiffer, H., 2005, Jahwes Kommen von Süden: Jdc 5; Hab 3; Dtn 33 und Psalm 68 in ihrem literatur- und theologiegeschichtlichen Umfeld, Vandenhoeck \& Ruprecht, Göttingen. (Forschungen zur Religion und Literatur des Alten und Neuen Testaments, 211).

Prinsloo, G.T.M., 1999, 'Reading Habakkuk as a Literary Unit: Exploring the Possibilities', Old Testament Essays 12, 515-535.

Prinsloo, G.T.M., 2001, 'Yahweh the Warrior: An Intertextual Reading of Habakkuk 3', Old Testament Essays 14, 475-493.

Prinsloo, G.T.M., 2002, 'Reading Habakkuk 3 in its Literary Context: A Worthwhile Exercise or Futile Attempt?', Journal of Semitics 11, 83-111.

Prinsloo, G.T.M., 2004, 'Habakkuk 1 - a Dialogue? Ancient Unit Delimiters in Dialogue with Modern Critical Scholarship', Old Testament Essays 17, 621-645.

Prinsloo, G.T.M., 2009, 'Petuchot/Setumot and the Structure of Habakkuk: Evaluating the Evidence', in R. de Hoop, M.C.A. Korpel \& S. Porter (eds.), The impact of Unit Delimitation on exegesis, pp. 196-227, Brill, Leiden. (Pericope 7).

Prinsloo, G.T.M., 2013, 'From Watchtower to Holy Temple: Reading the Book of Habakkuk as a spatial journey', in M. George (ed.), Constructions of space IV: Further developments in examining Ancient Israel's social space, pp. 132-154, Bloomsbury, London. (Library of Hebrew Bible/Old Testament Studies, 569).

Renz, T., 2003, Colometry and accentuation in Hebrew prophetic poetry, Hartmut Spenner, Waltrop. (Kleine Uuntersuchungen zur Sprache des Alten Testaments und seiner Umwelt, 4).

Ro, J.U-S., 2002, Die sogenannte "Armenfrömmigkeit" im nachexilischen Israel, De Gruyter, Berlin. (Beihefte zur Zeitschrift für die -alttestamentliche Wissenschaft, 322)

Roberts, J.J.M., 1991, Nahum, Habakkuk, and Zephaniah, Westminster/John Knox, Louisville. (Old Testament Library).

Rudolph, W., 1975, Micha - Nahum - Habakuk - Zephanja, Gütersloher Verlagshaus Gerd Mohn, Gütersloh, (Kommentar zum Alten Testament).

Sweeney, M.A., 1991, 'Structure, Genre and Intent in the Book of Habakkuk', Vetus Testamentum 49, 63-83. http://dx.doi.org/10.1163/156853391X00171

Sweeney, M.A., 1992, s.v. 'Habakkuk, Book of', in N.D. Freedman (ed.), Anchor Bible Dictionary, Doubleday, New York, vol. 3, pp. 1-6.

Széles, M.E., 1987, Wrath and mercy: A commentary on the books of Habakkuk and Zephaniah transl. G.F.A. Knight, Eerdmans, Grand Rapids. (International Theological Commentary). PMid:3302820

Thompson, M.E.W., 1993, 'Prayer, Oracle and Theophany: The Book of Habakkuk', Tyndale Bulletin 44, 33-53.

Tov, E., 1990, The Greek Minor Prophets scroll from Nahal Hever (8HevXIIgr) (The Seiâl collection 1), Clarendon, Oxford. (Discoveries in the Judean Desert, VIII).

Tov, E., 2000, 'The background of sense divisions in the biblical texts', in M.C.A Korpel \& J.M. Oesch (eds.). Delimitation criticism: A new tool in biblical scholarship, pp. 312-350, Van Gorcum, Assen. (Pericope 1).

Van der Woude, A.S., 1978, Habakuk - Zefanja, Callenbach, Nijkerk. (Prediking van het Oude Testament).

Vatican Ms. Urbinati 2, 1979, Pentateuch, Prophets and Hagiographa: Vatican Ms. Urbinati 2, Makor, Jerusalem. 


\section{Addendum 1}

TABLE 1a: Habakkuk 3: Text, translation and delimitation.

\begin{tabular}{|c|c|c|c|c|c|c|c|}
\hline \multirow{2}{*}{$\mathbf{1}^{1}$} & & & Atn 1 & Tip & 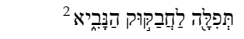 & $1 \mathrm{a}$ & A prayer of Habakkuk the prophet. \\
\hline & & & Sil 0 & Tip & שֵׁל שִׁגְנינוּת: & $\mathrm{b}$ & On 'Shigyonoth'. \\
\hline \multirow{20}{*}{$2^{3}$} & \multirow{4}{*}{$.1^{4}$} & \multirow{4}{*}{$.1^{5}$} & $\operatorname{seg} 1$ & Zar & 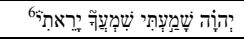 & $2 \mathrm{a}$ & YHWH, I have heard of your fame, I stand in awe! \\
\hline & & & Zaq 2 & $P a s ̌$ & 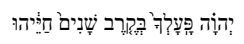 & $2 b$ & YHWH, your work - in the midst of years call it to life, \\
\hline & & & Atn 1 & Tip & 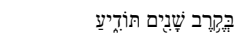 & c & In the midst of years, make (it) known! \\
\hline & & & Sil 0 & Tip & 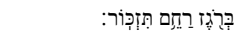 & $\mathrm{d}$ & In turmoil, remember mercy! \\
\hline & \multirow{7}{*}{$.2^{7}$} & \multirow{4}{*}{$.1^{8}$} & Zaq 2 & $P a s ̌$ & 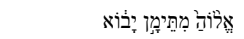 & $3 a$ & God comes from Teman, \\
\hline & & & Atn 1 & Tip & 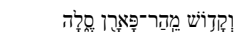 & $b$ & the Holy One from the mountain of Paran. Selah. \\
\hline & & & Zaq 2 & Paš & 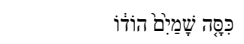 & $3 c$ & His splendour cover the heavens, \\
\hline & & & Sil 0 & Tip & 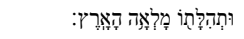 & $\mathrm{d}$ & and his praise fills the earth. \\
\hline & & \multirow{3}{*}{$.2^{9}$} & Zaq 2 & $\operatorname{Paš}$ & 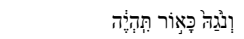 & $4 a$ & Brilliance as (sun)light appears \\
\hline & & & Atn 1 & Tip & 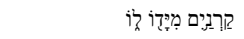 & $\mathrm{b}$ & rays (of light) are in his hand, \\
\hline & & & Sil 0 & Tip & 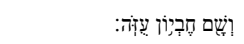 & c & there is the veil of his glory. \\
\hline & \multirow{9}{*}{$.3^{10}$} & \multirow{2}{*}{$.1^{11}$} & Atn 1 & Tip & 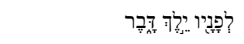 & $5 a$ & Before him goes Plague, \\
\hline & & & Sil 0 & Tip & 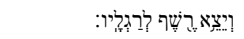 & $\mathrm{b}$ & Pestilence follows in his footsteps. \\
\hline & & \multirow{5}{*}{$.2^{12}$} & $\operatorname{Re} \underline{b} 3$ & $L^{e g}$ & 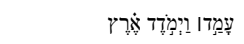 & $6 a$ & He stands - and causes the earth to tremble, \\
\hline & & & Zaq 2 & $P a s ̌$ & 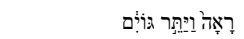 & $\mathrm{b}$ & he looks - and startles the nations. \\
\hline & & & Zaq 2 & $P a s ̌$ & 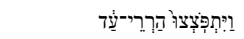 & $6 c$ & The everlasting mountains are shattered, \\
\hline & & & Atn 1 & Tip & 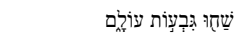 & $\mathrm{d}$ & the eternal hills bow down, \\
\hline & & & Sil 0 & Tip & 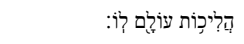 & e & these are his age old ways! \\
\hline & & \multirow{2}{*}{.313} & Atn 1 & Tip & 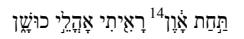 & $7 a$ & Under iniquity I see the tents of Kushan, \\
\hline & & & Sil 0 & Tip & 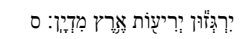 & $\mathrm{b}$ & they're trembling, the tent curtains of the land Midian. \\
\hline \multirow{21}{*}{$3^{15}$} & \multirow{8}{*}{$.1^{16}$} & \multirow{5}{*}{$.11^{17}$} & Zaq 2 & $\operatorname{Paš}$ & 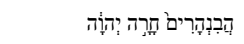 & $8 \mathrm{a}$ & Does it burn against the rivers, $Y H W H$, \\
\hline & & & Zaq 2 & $\operatorname{Paš}$ & 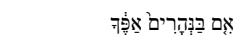 & $\mathrm{b}$ & is your anger toward the rivers, \\
\hline & & & Atn 1 & Tip & 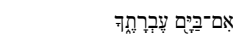 & c & is your wrath toward the sea, \\
\hline & & & Zaq 2 & $\mathrm{Paš}$ & 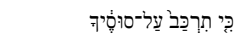 & $8 \mathrm{~d}$ & that you ride on your horses, \\
\hline & & & Sil 0 & Tip & 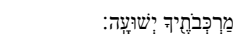 & e & your chariots of salvation? \\
\hline & & \multirow{3}{*}{$.2^{18}$} & Zaq 2 & $P a \check{s}$ & 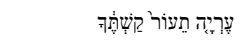 & $9 \mathrm{a}$ & Quickly you unsheath you bow, \\
\hline & & & Atn 1 & Tip & 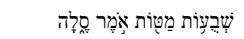 & $\mathrm{b}$ & commissioned is the majestic mace (by a) word. Selah. \\
\hline & & & Sil 0 & Tip & 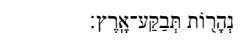 & c & With rivers you cleave the earth. \\
\hline & \multirow{7}{*}{$.2^{19}$} & \multirow{4}{*}{$.1^{20}$} & Zaq 2 & $\operatorname{Paš}$ & 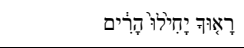 & $10 \mathrm{a}$ & Mountains see you - they writhe, \\
\hline & & & Atn 1 & Tip & 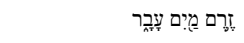 & $\mathrm{b}$ & a thunderstorm passes by. \\
\hline & & & Zaq 2 & $P a \check{s}$ & 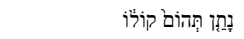 & $10 \mathrm{c}$ & The abyss gives its voice, \\
\hline & & & Sil 0 & Tip & 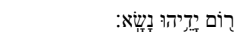 & $\mathrm{d}$ & on high he lifts up his hands. \\
\hline & & \multirow{3}{*}{.221} & Atn 1 & Tip & 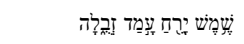 & $11 \mathrm{a}$ & Sun, moon stand in (their) lofty abode. \\
\hline & & & Zaq 2 & $P a \check{s}$ & 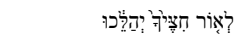 & $11 b$ & Brightly your arrows go forth, \\
\hline & & & Sil 0 & Tip & 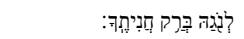 & c & brilliantly the lightning of your spear. \\
\hline & \multirow{6}{*}{.322} & \multirow{2}{*}{.123} & Atn 1 & Tip & 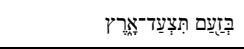 & $12 \mathrm{a}$ & In indignation you trample the earth, \\
\hline & & & Sil 0 & Tip & 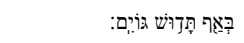 & $\mathrm{b}$ & in wrath you thresh the nations. \\
\hline & & \multirow{4}{*}{.224} & Zaq 2 & Paš & 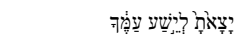 & $13 a$ & You go forth for the salvation of your people, \\
\hline & & & Atn 1 & Tip & 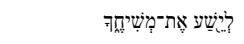 & $\mathrm{b}$ & for the salvation of your anointed. \\
\hline & & & Zaq 2 & $\operatorname{Paš}$ & 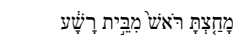 & $13 c$ & You shatter the head of the house of wickedness, \\
\hline & & & Sil 0 & Tip & 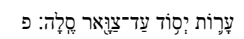 & $\mathrm{d}$ & to lay bare the foundation to the neck. Selah. \\
\hline
\end{tabular}




\begin{tabular}{|c|c|c|c|c|c|c|c|}
\hline \multirow{20}{*}{$4^{25}$} & \multirow{5}{*}{.126} & \multirow{3}{*}{.127} & Zaq 2 & $\operatorname{Paš}$ & 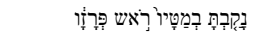 & $14 \mathrm{a}$ & You pierce with his own weapons the head of his warriors, \\
\hline & & & Atn 1 & Tip & 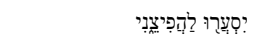 & $\mathrm{b}$ & while they storm in to scatter me. \\
\hline & & & Sil 0 & Tip & 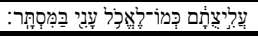 & $\mathrm{c}$ & Their rejoicing is as one who devours the poor in hiding. \\
\hline & & \multirow{2}{*}{$.2^{28}$} & Atn 1 & Tip & 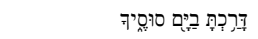 & $15 \mathrm{a}$ & You tread on the sea with your horses, \\
\hline & & & Sil 0 & Tip & 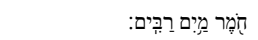 & $\mathrm{b}$ & the froth of the mighty waters. \\
\hline & \multirow{5}{*}{$.2^{29}$} & \multirow{5}{*}{$.1^{30}$} & $R^{e} \underline{b} 3$ & $L^{e g}$ & 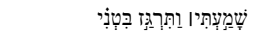 & $16 \mathrm{a}$ & I heard and my body trembled, \\
\hline & & & Zaq 2 & $P a s ̌$ & 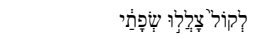 & $\mathrm{b}$ & at the sound my lips quivered, \\
\hline & & & Atn 1 & Tip & 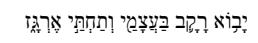 & c & rottenness enters into my bones and beneath me I tremble, \\
\hline & & & Zaq 2 & $P a s ̌$ & 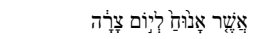 & $16 \mathrm{~d}$ & because I have to(OR: where I) wait for the day of distress \\
\hline & & & Sil 0 & Tip & 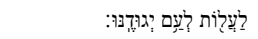 & e & to come for the people who are attacking us. \\
\hline & \multirow{10}{*}{$.3^{31}$} & \multirow{5}{*}{.132} & Zaq 2 & $P a s ̌$ & 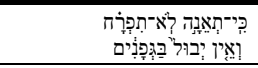 & $17 \mathrm{a}$ & $\begin{array}{l}\text { Although the fig tree does not blossom, } \\
\text { and there are no fruit on the vines, }\end{array}$ \\
\hline & & & Zaq 2 & $\mathrm{Paš}$ & 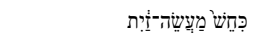 & $\mathrm{b}$ & the yield of the olive tree fails, \\
\hline & & & Atn 1 & Tip & 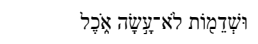 & c & and the fields do not produce food, \\
\hline & & & Zaq 2 & $P a s ̌$ & 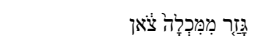 & $17 \mathrm{~d}$ & the flock is cut off from the fold, \\
\hline & & & Sil 0 & Tip & 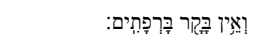 & e & and there are no cattle in the stalls, \\
\hline & & \multirow{2}{*}{$.2^{33}$} & Atn 1 & Tip & 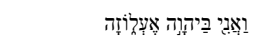 & $18 \mathrm{a}$ & yet I, in YHWH I will exult, \\
\hline & & & Sil 0 & Tip & 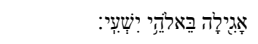 & $\mathrm{b}$ & I will rejoice in the God of my salvation. \\
\hline & & \multirow{3}{*}{.334} & Zaq 2 & $\mathrm{Pas̆}$ & 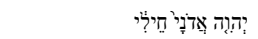 & 19a & YHWH my Lord is my strength, \\
\hline & & & Zaq 2 & $P a s ̌$ & 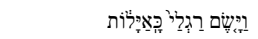 & $\mathrm{b}$ & he places my feet like those of the hinds, \\
\hline & & & Atn 1 & Tip & 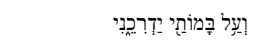 & c & on my high places he makes me walk. \\
\hline \multicolumn{3}{|l|}{$5^{35}$} & Sil 0 & Tip & 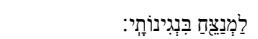 & $19 \mathrm{~d}$ & To the conductor. On my stringed instruments. \\
\hline
\end{tabular}

\section{Footnotes to Addendum 1}

1.The Septuagint ${ }^{\text {SBAaw }}$ and some manuscripts of the Vulgate demarcate $3: 1 \mathrm{ab}$ as a separate superscript.

2.Cola and lines are demarcated according to the major disjunctive Masoretic accents. Cf. De Hoop (2000a, 2000b) and Renz (2003:7-12, 37-40, 49, 54-55 and esp. 57-80) for a discussion of the system and a critical evaluation of the function of the accents. In Habakkuk 3:1-19 the end of cola are demarcated by:

Sillûq: 1b; 2d; 3d; 4c; 5b; 6e; 7b; 8e; 9c; 10d; 11c; 12b; 13d; 14c; 15b; 16e; 17f; 18b; 19d.

'Atnāḥ: 1a; 2c; 3b; 4b; 5a; 6d; 7a; 8c; 9b; 10b; 11a; 12a; 13b; 14b; 15a; 16c. Segôltâ: 2a.

Zāqēp parvum: 2b; 3a; 3c; 4a; 6b; 6c; 8a; 8b; 9a; 10a; 10c; 11b; 13a; 13c; 14a; 16b; 16d; 17b; 17c; 17e; 19a; $19 \mathrm{~b}$.

$R^{e} \underline{b} \hat{i}^{a}:$ 6a; $16 a ; 17 a$.

Sixty-six cola which combine to form 29 lines can be demarcated. Eight of the 29 lines are tricola (4abc; 6cde; 8abc; 9abc; 11abc; 14abc; 16abc; $19 a b c=28 \%), 1$ line is a monocolon $(19 d=3 \%)$, the remaining 20 lines $(67 \%)$ are bicola. Of these lines $3: 1 \mathrm{ab}$ and $3: 19 \mathrm{~d}$ can be regarded as a super- and subscript respectively. The poem proper thus consists of 27 lines, 8 tricola subscript respectively. The
$(30 \%)$ and 19 bicola $(70 \%)$

3.All Hebrew manuscripts consulted regard 3:1-7 as a section.

4.All Hebrew manuscripts consulted regard 3:1-7 as a section.

5.In Habakkuk 1 and 2 corroborative material in 1QpHab and manuscripts of the Septuagint aid modern interpreters in the endeavour to combine lines to form strophes. As already indicated, manuscripts of the Septuagint differ in their treatment of Habakkuk 3, writing the text either 'stichometrically' or using the apparently musical notation (translated in Greek as $\delta$ ió $\psi \alpha \lambda \mu \alpha$ ) as the main delimitation criterion. 10pHab does not, of course, contain Habakkuk 3. Using especially the criterion of parallelism, and taking $3: 1 \mathrm{ab}$ as a separate superscript and 3:19d as a subscript, 18 strophes can be as a separate supenstipt and $3: 19 d$ as a subscript, 18 strophes can be demarcated, corresponding in each case with the Masoretic verse. Note that in Biblia Rabbinica every Masoretic verse is followed by a space. It confirms the observation by Korpel (2000.41) that the soph pasuq acts as a fairly reliable guide to demarcate strophes. In 2a the emphasis upon יהוה at the beginning of the colon confirms that a new strophe commences.
6.The Masoretic accents are followed in the demarcation of the four cola in 3:2. It differs from the traditional demarcation in virtually all commentaries:

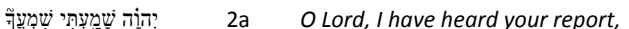

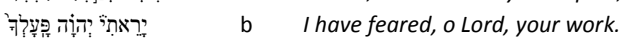

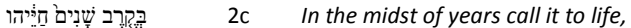

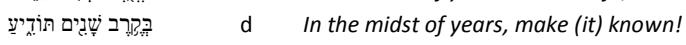

e e In turmoil, remember mercy!

Cf. Hiebert (1986:60-63) for a discussion of this 'traditional' delimitation. Renz (2003:114) follows the Masoretic accentuation in his analysis of Habakkuk 3.

7.The change of subject is indicative of the beginning of a new stanza.

8.In 3a the emphasis upon אלוה at the beginning of the colon confirms that a new strophe commences.

9.In 4a the unusual syntax confirms that a new strophe commences.

10.The change of subject is indicative of the beginning of a new stanza. Some manuscripts of the Vulgate also mark $5 a$ as the beginning of a new section.

11.In 5 a the unusual syntax confirms that a new strophe commences.

12.In $6 a$ the occurrence of two verbal forms at the beginning of the colon confirms that a new strophe commences.

13.In 7a the unusual syntax confirms that a new strophe commences.

14.The demarcation and translation of the colon is controversial. It is often read together with $6 \mathrm{e}$ and translated by 'those are his ancient ways as punishment for iniquity' (cf. Rudolph 1975:234-235; Van der Woude 1978:62). Renz (2003:46-48) argues that תחת און should be read together with the following phrase and that the zāqēp parvum should, in this instance, be ignored. It is confirmed by De Hoop (2000b:86) who maintains that a zāqēp parvum, when marking the second word in a colon 'while the preceding (first) word bears a conjunctive accent' does not mark the end of a colon.

15.All Hebrew manuscripts consulted regard 3:8-13 as a section

16.The change of subject is indicative of the beginning of a new stanza. 
17.In $8 \mathrm{a}$ the interrogative particle at the beginning of the colon confirms that a new strophe commences.

18.In 9a the emphatic repetition of the root עור at the beginning of the colon confirms that a new strophe commences.

19.The change of subject is indicative of the beginning of a new stanza.

20.In 10a the occurrence of two verbal forms at the beginning of the colon confirms that a new strophe commences.

21.In 11a the unusual syntax confirms that a new strophe commences.

22.The change of subject is indicative of the beginning of a new stanza.

23. In 12a the unusual syntax confirms that a new strophe commences.

24.In 13a the occurrence of Perfect verbal forms following upon the Imperfect forms in 12ab suggests the beginning of a new strophe.

25. Hebrew manuscripts consulted regard 3:14-19 as a section. It is also the case in the Septuagint ${ }^{\text {SBAOW. }}$.

26.The change of subject is indicative of the beginning of a new stanza.

27.In 14a the unusual syntax confirms that a new strophe commences.

28. In 15 a the unusual syntax confirms that a new strophe commences. Some manuscripts of the Vulgate mark 15 a as the beginning of a new paragraph.
29.The change of subject is indicative of the beginning of a new stanza.

30.In 16a the occurrence of two verbal forms at the beginning of the colon confirms that a new strophe commences.

31.The change of subject is indicative of the beginning of a new stanza.

32.In 17a the occurrence of the deictic particle כי confirms that a new strophe commences.

33.In 18a the occurrence of the pronoun in an emphatic position at the beginning of the line confirms that a new strophe commences. Some manuscripts of the Vulgate mark 18a as the beginning of a new paragraph.

34.In 19a the emphasis upon יהוה at the beginning of the colon confirms that a new strophe commences.

35.Ancient Hebrew and Greek manuscripts do not regard 3:19d as a separate unit. The Septuagint did not regard it as a subscript but relates it to the preceding 3:19c, evidently relating the Hebrew נצח to 'conquer,' meaning not attested in Biblical Hebrew. In the Septuagint Habakkuk 3:19cd reads as follows:

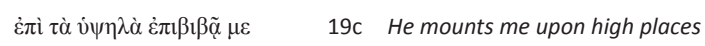

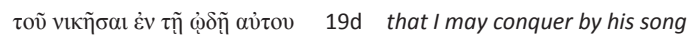

It is demarcated as a separate section here because of parallels in the Book of Psalms where it clearly functions as part of the superscript. 